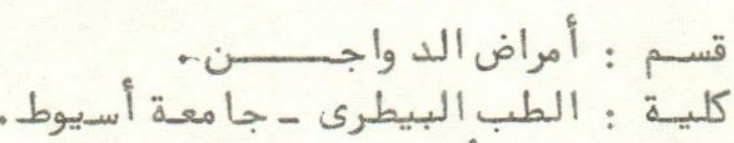

$$
\begin{aligned}
& \text { رئيس القسم : أ.د / ابراهيم حسن سكر. }
\end{aligned}
$$

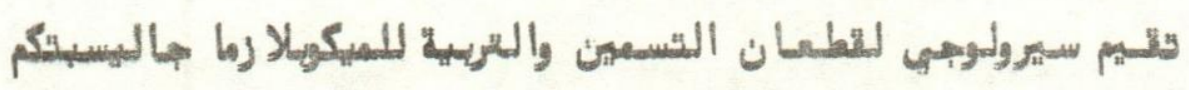

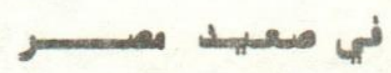

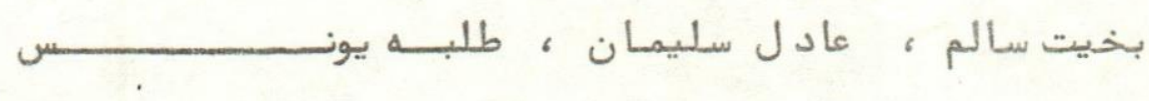

اشتمل البحث على تقبيم بعض الاختبارات السيرولوجيه مثل اختبـــــــــار

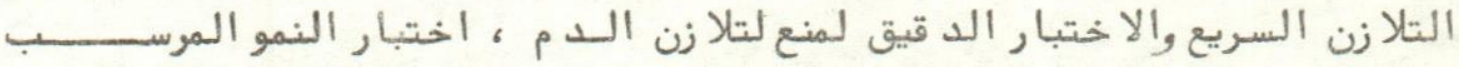

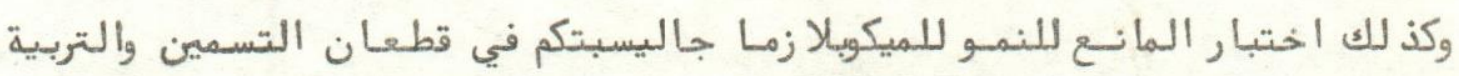

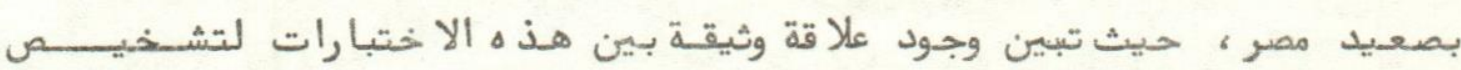

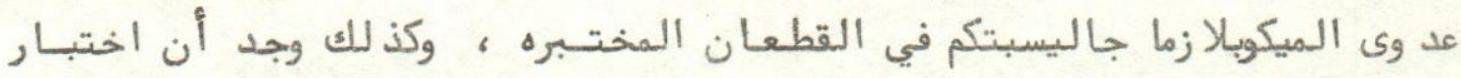

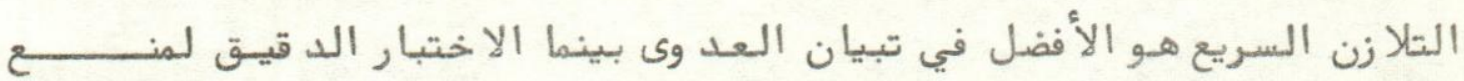

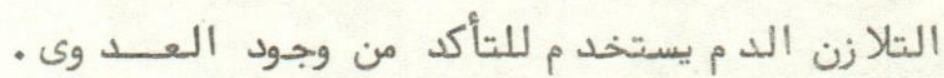


Dept. of Poultry Diseases, Faculty of Vet. Med., Assiut University, Head of Dept. Prof. Dr. I. H. Sokkar.

\title{
SEROLOGICAL EVALUATION OF BROILER AND COMMERCIAL LAYER FLOCKS FOR MYCOPLASMA GALLISEPTICUM INFECTION IN UPPER EGYPT \\ (With One Table)
}

\author{
By \\ B.M. SALEM; A.M. SOLIMAN and T.Y. ABD-EL-MOTTELIB
}

(Received at 19/5/1985)

\begin{abstract}
SUMMARY
Serological evaluation of Poultry flocks for Mycoplasma gallisepticum infection in the area of the Upper Egypt was demonstrated by using serum plate agglutination ( $P$ P) together with microheamagglutination-inhibition ( $m$ H I), Growth precipitation ( $G P$ ) and Growth-inhibition ( $G$ I) tests. A good correlation was observed between $G$ P, $m$ H I, S P A and G I -tests for the early confirmation of $M$. gallisepticum infection in the examined flocks. Results indicated that the $S$ P $A$ test could be utilized for screening while $\mathrm{m} \mathrm{H} \mathrm{I}$ for more confirmation.
\end{abstract}

\section{INTRODUCTION}

Avian mycoplasma organisms are one of the etiological agents for respiratory diseases of poultry not only in Egypt but also throughout the world causing great economic losses.

There are various serological tests used for the diagnosis of the disease, Serum Plate agglutination (SPA) and Haemagglutinatin ( $\mathrm{HI}$ ) tests which are used routinely to detect antibodies to M. gallisenticum infection (ADLER, 1954; EDMINSTER, 1974; SAHU and OLSON, 1975). Also Growth -precipitation test was employed to evaluate the test reaction in broiler breeder and layer flocks (SAHU and OLSON, 1975), while Growth -inhibition (GI) test was carried out by CLYDE, 1964.

The aim of this work is to detect the status of M. gallisenticum in broiler and layer flocks at the area of the Upper Egypt by using various serological tests and slso to determine their efficacy.

\section{MATERIAL and METHODS}

\section{Sera and antigens:}

A total of 375 serum samples were collected from various broiler breeder and layer flocks at the area of Upper Egypt (Assiut, Sowhag and El-Minea governorates).

The sera were tested against $M$. gallisepticum staind antigen obtaind from Salsbary Laboratories, Charles, lowa, U.S.A., by the serum plate agglutination test that was carried out after ADLER, 1954 and for M. gallisepticum by the Haemagglutination-inhibition (HI-test) that 


\section{B.M. SALEM, et al.}

was conducted after CRAWLEY and FAHEY, 1957. The HI-antigen was supplied by the Mycoplasma section, Animal health research instituite, Dokki.

For the Growth-precipitation test, freshly harvested antigens were prepared and used as described by SAHU and OLSON, 1975 and were kept at $20^{\circ} \mathrm{C}$ befor solubilization or concentration, while antigens for the Growth-inhibition test were prepared from the locally isolated M. gallisepticum strain and the test was carried out after CLYDE, 1964.

\section{RESULTS}

The results of the serological survey are illustrated in Table (1).

\section{DISCUSSION}

From the table it is clear that the serum plate agglutination (SPA) test tends to be more sensitive and high levels of reactors were detected in both broiler and layer flocks. Where the HI-reaction appeared to be more superior than the SPA-test and therefore of great value for the diagnosis of $\mathrm{M}$. gallisepticum infection. High titers of Hl-antibodies were detected in broiler flocks (1:640) and (1:80) in layer flocks; also flocks showing high degree of SPA-test positive have usually higher HI-titers.

These results are in agreement with (ROBERTS, et al. 1957; ROBERTS, 1969; VERDMAN and YODER, 1969; SAHU and OLSON, 1975) where the previous authors recorded that after natural or artificial infection with avian mycoplasmas, the antibody response is first detected by SPA-test as early as few days after infection and the HI-test does not become positive until approximatally two weeks after infection. Incorporation of the growth-precipitation (GP) test along with SPA and HI- tests would help in correct evaluation of the naturally infected flocks with $M$. gallisepticum. Also a good correlation between GP, HI and SPA-test for the early confirmation fo $M$. gallisepticum infection in flocks was observed, where precipitating antibodies were detected in all positive serum samples with the SPA and HI-test, that is in agreement with SAHU and OLSON, 1975 who recorded that precipitin antibody remains constant for a long time. Results of the Growth-inhibition (GI) test revealed that the test was sensitive but not specific for detecting types of antibodies, but reliable for diagnosis of $M$. gallisepticum infection, these results are in confirmation with observations recorded by DIREKS, et al. 1967.

The results of this study indicated that $M$. gallisepticum is highly spreaded in broiler and layer flocks at the area of the Upper Egypt and also ensure on the importance of the GP-test together with the (m HI) and the (SPA) tests to evaluate poultry flocks for M. gallisepticum infection in case of isolation failure.

\section{REFERENCES}

Adler, H.E. (1954): A rapid slide agglutination test for the diagnosis of chronic respiratory disease in the field and in laboratory-infected chickens and turkyes. 90th Ann. Meeting, AVMA, 1954, 346-349.

Clyde, W.A. (1964): Mycoplasma species identification based on growth-inhibition test by specific antisera. J. immunology 92: 958-965. 


\section{MYCOPLASMA GALLISEPTICUM IN CHICKEN}

Crawley, J.F. and Fahey, J.E. (1957): The use of the haemagglutination-inhibition test for the control of the PPLO-infection in poultry. J. Americ. Vet. Med. Associ, 130: 187-190.

Dierks, R.E.; Newman, J.A. and Pomeroy, B.S. (1967): Characterization of avian mycoplasmas. Amn NY Acad. Sci., 143: 170-189.

Edminster, T.W. (1974): Cited by Sahu and Olson, 1975.

Roberts, D.H.; Olesiuk, O.M. and Van-Roekel, H. (1967): Immunologic response of fowl to $M$. gallisepticum and its relationship to latent infection. Am. J. Vet. Res. $\overline{28}$ 1135-1152.

Roberts, D.H. (1969): Serological response produced in chicken by three strains of M. gallisepticum. J. App. Bact., 32: 395-401.

Sahu, S.P. and Olson, NO. (1975): Use of the Agar-Gel precipitation test to evaluate broiler breeder and commercial flocks for $\underline{M}$. gallisepticum infection. Avian Disease 20(3): 563-573.

Wardman, T.H. and Yoder, H.W. (1969): Preparation of M. synoviae haemagglutination antigen and its use in the haemagglutination-inhibition test. Avian Disease 13(3): 654-661. 
B.M. SALEM, et al.

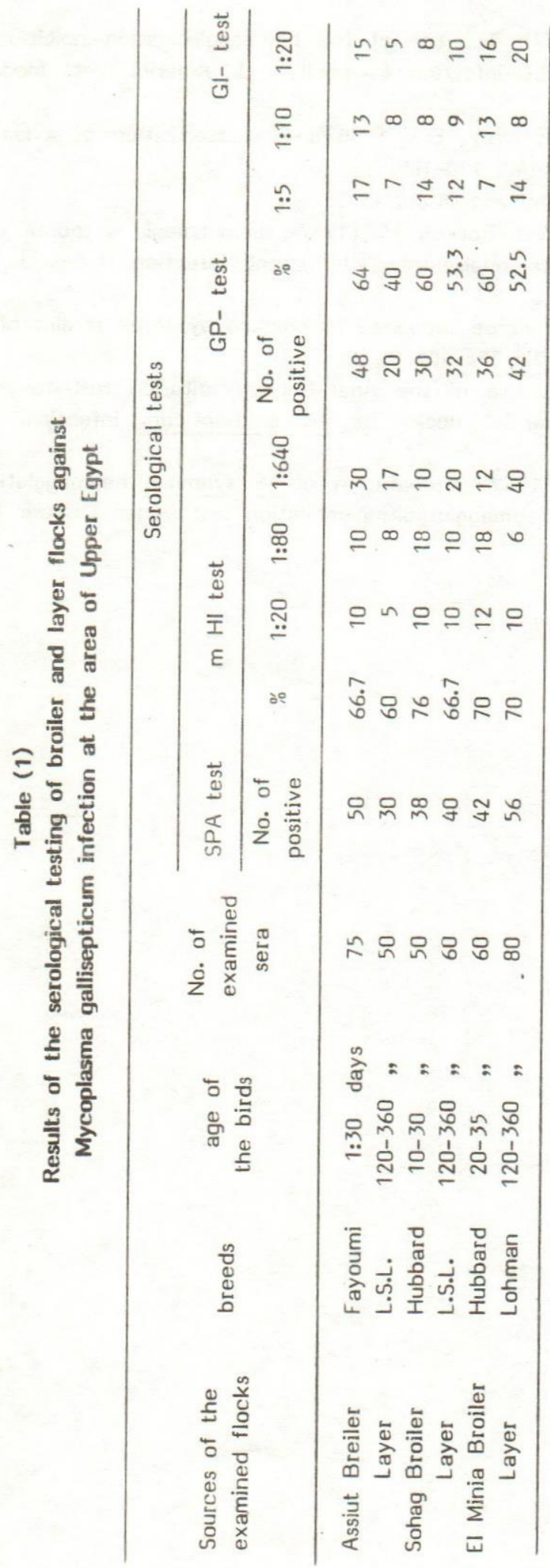

